\title{
Christoph Schwöbel* \\ Justice and Freedom: The Continuing Promise of the Reformation
}

https://doi.org/10.1515/nzsth-2017-0034

Summary: Against the backdrop of the debates on the appropriate understanding of the Reformation in the context of the 500 year anniversary of the Reformation the attempt is made to elaborate the continuing promise of the Reformation with regard to the understanding of justice and freedom. The view of justice as a creative gift and the understanding of freedom as promise presuppose that the character of the Reformation can be understood as the reconfiguration of the traditional theological authorities. The understanding of reality as rooted in the creative justice of God who alone is free because God is his own future is applied in the Lutheran art of making distinctions which relate God's creative being and action to the created being and action of humans. The continuing promise of the Reformation is the discovery of this unconditional promise and of the way it is witnessed in the Church. As the creature of God's justifying word the life of the church has the character of an embodied promise.

Keywords: Reformation, Luther, Gerechtigkeit, Rechtfertigung, Freiheit, Kirche

Zusammenfassung: Vor dem Hintergrund der Auseinandersetzungen um das angemessene Verständnis der Reformation im Jahr ihres 500jährigen Jubiläums wird in diesem Aufsatz versucht, die bleibende Verheißung der Reformation an Luthers Verständnis der Gerechtigkeit und der Freiheit herauszuarbeiten. Sowohl die Sicht der Gerechtigkeit als unbedingte schöpferische Gabe als auch die Sicht der Freiheit als Verheißung machen deutlich, dass der Charakter der Reformation als Rekonfiguration der traditionellen theologischen Autoritäten verstanden werden kann. Die Begründung aller Wirklichkeit in der schöpferischen Gerechtigkeit Gottes, der allein seine eigene Zukunft ist und so unbedingte Freiheit besitzt, wird in der lutherischen Kunst der Unterscheidungen umgesetzt, die Gottes schöpferisches Sein und Handeln zum geschöpflichen Dasein und Handeln der Menschen in Beziehung setzen. Die bleibende Verheißung der Reformation ist die Entdeck-

*Corresponding author: Christoph Schwöbel, Institut für Hermeneutik und Dialog der Kulturen, Ev.-theol. Fakultät Tübingen, Liebermeisterstr. 12, D-72076 Tübingen,

E-Mail: christoph.schwoebel@uni-tuebingen.de 
ung dieser unbedingten Verheißung und ihre Bezeugung in der Kirche. Als Geschöpf des rechtfertigenden Wortes Gottes ist sie verleiblichte Verheißung.

Schlüsselwörter: Reformation, Luther, justice, freedom, church

\section{Contentious Celebrations}

The Wittenberg Reformation started with a controversy in theology and an invitation to an academic disputation. Since the publication of the so-called 95 Theses on the $31^{\text {st }}$ of October 1517, the debates triggered by the questions raised and by the answers suggested by Martin Luther have not subsided. Many of the issues touched upon in Luther's theses have contributed to a continuing background conversation on the intellectual, political, cultural and social developments, first in Europe, and over the following centuries also world-wide. Not only the pluralisation of the Christian churches, often occurring in parallel with the developments of territorial and political independence by the principalities, but also the attempts to create new forms of unity in the Church and in the secular realm have shaped what we call the modern world. The effect of the Reformation cannot only be described as "Europe's House Divided", as the sub-title of Diarmaid McCulloch's Reformation history suggests. ${ }^{1}$ The formation of Roman Catholicism as it was undertaken in response to the Reformation at the Council of Trent must also be seen as a major effect of the Reformations in the European church, radiating, with often contradicting effects, into all spheres of life, and eventually to all corners of the globe. Today we also find comprehensive interpretations of the effects of an allegedly unintended Reformation, perceiving in our current cultural "hyperpluralism" one of the after-effects of the Reformation, a thesis defended in the work of the American Catholic historian Brad S. Gregory. ${ }^{2}$

In Germany where the Reformation began in one of its important strands, the run-up to the 500 year anniversary has been characterised by fierce debates about the character of the Reformation, especially among the church historians: Was it a modification of the belief-system and the social organisation of the late medieval church, taking up elements that had been around for a long time and pushing them to the foreground? Or was it an innovation, a new departure that cannot be explained by its antecedent conditions but must be interpreted in terms of its

1 Cf. Diarmid MacCulloch, The Reformation: Europe’s House Divided 1490-1700 (London: Penguin 2004).

2 Cf. Brad S. Gregory, The Unintended Reformation: How a Religious Revolution Secularized Society (Boston, Mass: Harvard UP, 2012). 
subsequent effects? Was Luther a medieval or a modern person? Was he a Protestant or a Catholic? Or should we overcome such alternatives and see him, his theology and the Reformation it triggered, as an example of Protestant or evangelical Catholicism, transforming the insights of Christian theology so that they became an impetus for the rise of modernity ${ }^{3}$ While the historians find it difficult to agree among themselves about the character of the Reformation, they suddenly present a united front over against the Protestant churches or the systematic theologians when the latter attempt to state the significance of the Reformation for today's church and society. Sometimes the discussions seem to be trapped between a radical historicization on the one hand and an equally radical attempt to update the orientations of the Reformation to make them relevant for our situation today.

Both programmatic orientations are in themselves questionable. Can a historical event simply be explained in terms of selected antecedent factors that seem to trigger it? Is not the subsequent history also part of seeing a historical event in connection with the processes it inaugurated, continued or curtailed? Whenever we raise a historical question we ask how our own present has come about. Furthermore, can we really update the insights of the Reformation without first acknowledging the strangeness, the otherness of Luther's world of thought and feeling, although we might very well be able to understand this strangeness by analogical extension from the experience of our own times? The acknowledgment

3 An impression of the debate can be gleaned from comparing the books of prominent German church historians. Cf. Volker LEPPIN, Die fremde Reformation. Luthers mystische Wurzeln (Munich: Beck, 2016); Thomas Kaufmann, Erlöste und Verdammte. Eine Geschichte der Reformation (Munich: Beck, 2016); Irene Dingel, Reformation: Zentren - Akteure - Ereignisse (Göttingen: Vandenhoeck. For a Roman Catholic theological view cf. Walter Kardinal KASPER, Martin Luther. Eine ökumenische Perspektive (Ostfildern: Patmos, 2016); Peter Neuner, Martin Luthers Reformation. Eine katholische Würdigung (Freiburg: Herder, 2017). The debate between the different strands of Protestant theology and Roman Catholic theology in its variety is documented in: Christian DAnz/ Jan-Heiner Tưck (eds.), Martin Luther im Widerstreit der Konfessionen. Historische und theologische Perspektiven (Freiburg: Herder, 2017). - One of the most impressive achievements is the comprehensive description between the Martin Luther's Reformation and the development of law in: Martin Heckel, Martin Luthers Reformation und das Recht. Die Entwicklung der Theologie Luthers und ihre Auswirkungen auf das Recht unter den Rahmenbedingungen der Reichsreform und der Territorialstaatsbildung im Kampf mit Rom und den "Schwärmern" (Tübingen: Mohr, 2016). Historical research outside Germany sees the Reformation in terms of a plurality of reformations in Europe and outside of Europe cf. Carlos N. EIRE, Reformations. The Early Modern World, 1450-1650 (New Haven: Yale UP, 2016). The theological challenge consists, not least, in clarifying the theological difference between the Lutheran Reformation and the pluriformity of reforms and so relate it to the Reformations which built on the reconfiguration of theological authorities introduced in Luther's theology. 
of the strangeness of the cultural world of the Reformation is at least a salutary reminder that we should be careful not to project what we like about modernity back to its alleged roots in the Reformation.

The most common pattern, long established in the genealogy of a certain kind of modernity, consists in understanding the Enlightenment and its call for autonomy as a consequence of the Reformation. However, if there is anything that characterises Luther's thought at its core, it is not self-legislation - he had remarkably critical ideas about the self as curved in upon itself and about the law which cannot be fulfilled, but judges and kills. Rather, the core element of Luther's theology would have to be called something like alloepangelia, the promise made by another, by God in Christ, made certain for us by God the Holy Spirit, which defines the standpoint and provides the framework for our orientation in relation to God, to one another and in the world. This is the basis for taking a stand against the supreme worldly and ecclesial authorities as Luther did at the Diet of Worms in 1521, an event which demonstrates perhaps more than the 95 theses the significance of the Reformation. ${ }^{4}$

The most promising approach for interpreting the Reformation historically by taking the theology of the Reformation seriously, and theologically by paying attention to the historical character of all theological concepts, seems to me to understand it as a reconfiguration of the traditional ways of understanding the doctrinal system and social organisation of Western Christianity. This reconfiguration started in a situation of acute dissent arising out of pastoral conflicts, occasioned by the selling of indulgence letters and its underlying theological justifications, as a reconfiguration of the authorities for Christian faith, its explication in Christian theology and its practice in Christian worship and the Christian life. The main tool for this reconfiguration is the practice of making distinctions and of proposing and testing out reconnections. Distinctions which do not refer to one specific Christian doctrine but to the whole of the doctrinal scheme of Christian and affect the whole of Christian life and worship are the distinctions between:

- between the work and power of God and the work and power of human creatures;

- between Scripture as the paradigmatic witness to God's work in Christ and in Israel and tradition as the history of the transmission and interpretation of the Gospel;

- between law and gospel;

4 Joachim Knape, 1521. Martin Luthers rhetorischer Moment oder die Einführung des Protestes (Berlin/New York: de Gruyter, 2017). 
- between faith and works;

- between sin and faith;

- between the spiritual realm as God's way of leading the world to salvation and the worldly realm as the field of responsible human action, based upon God's conservation of the regularities of social interaction and their natural presuppositions, directed towards the well-being and the order of a good society and not to salvation.

The legacy of the Lutheran Reformation, based on this reconfiguration, consists not least in the art of making distinctions and of suggesting the right relationship of what has so been distinguished. The pattern established in this way is still effectively represented by the so-called exclusive particles of Reformation theology: solus Christus, sola gratia, sola fide and sola scriptura. Is there a promise contained in this legacy that could open up constructive vistas for critically interpreting and shaping the Christian life today in our different and connected contexts?

\section{The Gift of Justice}

It used to be a commonplace in Lutheran theology in the last quarter of the $20^{\text {th }}$ century that what was regarded as the central doctrinal tenet of Lutheran theology, the doctrine of justification, no longer makes sense in the modern world. Should we not search for other interpretative categories to make the doctrine of justification accessible again? When these thoughts were first proposed in the mid-1970ies there was soon a thoughtful response by the German philosopher Odo Marquard (1926-2015). In his view, the modern world is characterized by an excessive tendency to place every individual in front of a tribunal in order to justify themselves. The eclipse of the question of theodicy, the justification of God in view of the evil in the world, has made the question of anthropodicy of paramount importance, Marquard argues. ${ }^{5}$ The Last Judgement is anticipated in every context of life by the need to offer constant justifications. Marquard diagnosed in our times an uneasy ambivalence between the demand for total account-

5 Cf. Odo Marquard, „Rechtfertigung. Bemerkungen zum Interesse der Philosophie an der Theologie“, in: Giessener Universitätsblätter 1 (1980), 78-87. The dialectic between th excessive demand for justification after the demise of theodicy and the escape into unaccountability is described in Marquard's essay “Der angeklagte und der entlastete Mensch in der Philosophie des 18. Jahrhunderts, in: Odo MARquard, Abschied vom Prinzipiellen (Stuttgart: Reclam, 1981), 39-66. 
ability and the escape in equally radical non-accountability: "I am what I am and what I am needs no excuses."

It seems to me that Marquard was right in his diagnosis of our situation as confronting us with the permanent demand for justification, as a situation deeply characterized by the "loss of grace". If we, just by way of experiment, go through the different areas of our life, we find that we almost feel compelled to offer justifications for the way we live. The different aspects in which we experience our society as a "society of global risks" 6 determine our situation as one in which we are in constant need of (self-)justification and also experience the desire to escape from excessive accountability.

Not only the ecological crisis, the population crisis and its consequences for the demographic forecasts but also the global transformation of societies with a market economy to market societies, long ago analysed by Karl Polanyi as The Great Transformation, where everything seems to be negotiated on the market and everything is to be determined by its market-value, has made the situation worse. ${ }^{7}$ The underlying market logic of supply and demand easily leads to a situation were everything becomes a marketable commodity, a development fuelled by the underlying view of what it means to be human, i.e. to be a successful competitor in a world where every value, be it material or spiritual, seems to be regulated by market-type exchanges.

The establishment of the economic paradigm of competition and market-type exchanges is certainly one reason why problems of justice have become omnipresent in our societies. A system of social interaction where there will always be winners and losers is bound to create problems of social justice and challenge the possibility of equality and fairness in society. How can such a society where everything follows the logic of commutative justice still exemplify the just distribution of goods and values? How does the principle suum cuique help to provide to each what they are due in such a social constellation? Not surprisingly, most political issues we are dealing with at present, whether locally, nationally or globally have a strong component of debates on justice: What does justice mean with regard to the widening gap between rich and poor nations, between the rich and the poor in our nation? How would justice as just distribution of goods and services have to be organised if we look at the chances of participation in political life, in the opportunities of education and of benefitting from the cultural goods

6 Ulrich Beck, World Risk Society (Cambridge/Oxford/Boston/NewYork: Polity, 1999).

7 Cf. Karl Polanyi, The Great Transformation [1957] (Boston: Beacon press, ${ }^{11} 1971$; Pнilip BoвBitt, The Shield of Achilles: War, Peace and the Course of History, New York 2002 
and values that inextricably belong to a good society? Is the common good in all its aspects a necessary correlate of justice in its different dimensions?

One cannot understand the significance of the Reformation message, let alone the doctrine of justification, if it is not squarely placed in the context of discussions on justice. Luther's question "How can I find a gracious God?" is in his day to be understood in the most radical eschatological sense: "How can I be saved in the Last Judgment, before the judgment seat of Christ?" It seems that one only has understood the impact of the Reformation if one can imagine what it meant that in a time when groups of penitents, flagellating themselves, processed through the cities, one man, the Reformer Martin Luther, could talk of the Last Judgment as "the dear Judgement Day". This change from utmost existential anxiety and horror to the courage to live trusting in God's grace, confident that God's judgment of grace, already experienced in the promise of the Gospel in word and sacraments as radical liberation here and now, will then, on the Last Day be confirmed by Christ - whatever else this day might reveal about each of us. It is a momentous change in the understanding of justice, God's justice and justice in the world, which is at the heart of this dramatic change of attitude. Could recovering this understanding of God's justice be part of the continuing promise that the Reformation holds for our churches?

In the preface to the collected edition of his Latin works Luther tells the story of how he discovered the meaning of "justice of God" in Romans 1:17. ${ }^{8}$ The preceding verse 1:16 reads: "For I am not ashamed of the gospel; it is the power of God for salvation to everyone who has faith, to the Jew first and also to the Greek." Then follows: "For in it the righteousness of God is revealed ..." In recalling the year 1519, during the time of his second exposition of the Psalms in his lectures, Luther says:

"I hated that word, 'justice of God', which, by the use and custom of all my teachers, I had been taught to understand philosophically as referring to formal or active justice, as they call it, i.e., that justice by which God is just and by which he punishes sinners and the unjust."

It is clear that Luther here thinks of justice in the sense that God is the ultimate standard of justice, and judges people according to this standard on the basis of their actions. The justice of God in relation to humans is here juridical and punitive. This however, leads to a problem. Luther describes himself as a "blameless monk". Nevertheless before God he felt as a sinner with a troubled con-

8 Luther's Preface to his Latin Writings is easily accessible here: http://www.projectwittenberg. org/pub/resources/text/wittenberg/luther/preflat-eng.txt. 
science. If humans are already entangled in original sin and cannot do the good they want to do, is it fair that the Ten Commandments confront them with demands for their actions they cannot meet as sinners? Furthermore, as if the situation were not already hopeless enough, God then confronts the Christian with the Gospel which in Luther's day was read as nova lex Christi, the new law of Christ, radicalizing the demands of the Ten Commandments. On this reading, Romans 1:17 is to be understood: In the gospel, in the radicalisation of law by the law of Christ, the justice of God is revealed, and measured by that standard, no one could ever hope to appear just before the judgement seat of Christ. Luther describes vividly how he hated God for confronting humans with an impossible demand, but how he nevertheless continued to labour to get the passage in Romans 1 clear. Gaining a new understanding of the justice of God is then described in the language of a disclosure experience:

I meditated night and day on those words until at last, by the mercy of God, I paid attention to their context: "The justice of God is revealed in it, as it is written: 'The just person lives by faith."' I began to understand that in this verse the justice of God is that by which the just person lives by a gift of God, that is by faith. I began to understand that this verse means that the justice of God is revealed through the Gospel, but it is a passive justice, i.e. that by which the merciful God justifies us by faith, as it is written: "The just person lives by faith." All at once I felt that I had been born again and entered into paradise itself through open gates.

In a way this disclosure experience already shows the reconfiguation of the theological authorities. Luther continues to rely on Scripture as opposed to the understanding of his teachers. And he lets Scripture be its own interpreter, by interpreting one passage intertextually through the context. If the one who is just lives by faith, as the quotation from the prophet Habakuk has it, then justice cannot be understood as a juridical assessment of the quality of human actions. Justice must be understood not as acquired by just actions, but as being constituted by faith. How can faith, ultimate trust in God, make a person just? Only if faith is not a human work but a divine work in us, and if the God who constitutes faith is also the one who constitutes justice, by making the sinner just through his own, God's justice. And if that is so, the preceding verse requires a very different understanding of the Gospel. The Gospel must now be understood as the "power of God for salvation", as the way in which God communicates his justice to sinners who can only receive it passively in the constitution of faith which, after having been constituted for the believer, is then practised by the believer in the active life of faith. Luther continues:

"Immediately I saw the whole of Scripture in a different light. I ran through the Scriptures from memory and found that other terms had analogous meanings, e.g., the work of God, 
that is, what God works in us; the power of God, by which he makes us powerful; the wisdom of God, by which he makes us wise; the strength of God, the salvation of God, the glory of God."

The new meaning that Luther discovered understands the justice of God, first of all, as creative justice, making the sinner just, not on the basis of the sinner's actions, but exclusively on the basis of God's own being, will and work. And secondly, that is the wider implication which Luther discovers by going through other biblical key terms like work, power, wisdom, strength, salvation and glory, it is a communicative attribute of God which God communicates effectively to those who in whom he creates faith, precisely as certainty concerning God's creative justice. Communication creates communion and so those who are made just by God are the ones who are destined to live in communion with God.

However, communicative attributes also require to be communicated, they cannot just be tacitly assumed, they must be explicitly communicated. Scripture is for Luther just this way of communication, and since Scripture as the written testimony to the Gospel always drives to concrete interpersonal communication as the living voice of the Gospel, justice must be communicated in speech acts in which we are promised: "You are justified", "your sins are forgiven", "welcome to the covenant of grace". Here, as in all aspects of his theology, Luther's view of Scripture and its authority points to the use of Scripture in situations of worship.

If we want to illustrate this understanding of justice in terms of the philosophical discussion on justice it seems to be closest to the understanding of justice as recognition and acknowledgment, recently revitalized by the work of the Frankfurt philosopher Axel Honneth. ${ }^{9}$ God unconditionally recognizes the sinner as his creature with whom he wants to live in communion. The "re" in recognition points not to a quality in humans but to a quality in God, his faithfulness to his own character, will and works. God recognizes sinners as his creature, created in the image of God and destined to find the fulfilment in communion with God.

If that is justification, being made just by the creative justice of God and so trusting in it in a way that is exclusively enabled by God, does it only apply to Christians who have received faith as the gift of God? Luther's determination to

9 The best short summary of this view is Axel Honneth, The I in We: Studies in the Theory of Recognition, trans. Joseph Ganahl (Malden, MA: Polity Press, 2012). On the theological task of developing an understanding of justice from God's creative justice cf. Christoph SchwöBEL, "The Justice of God and Justice in the World, “ in: T. Boer/H. MaAt/A. Meesters/J. Muis (eds.), Van God gesproken: over religieuze taal en relationele theologie, (Zoetermeer: Boekencentrum, 2011), 217-232. 
search Scripture for other ways of characterizing God's relationship to his creatures seems to point in another direction. Being justified by God has the same structure as being created by God ex nihilo. Just as creatures contribute nothing to their coming into existence, so sinners contribute nothing to their justification. The disclosure experience opens up the understanding of how God relates to his creatures in every way. Therefore this particular understanding of justice does not only apply to Christians but applies universally to every human being, even to every creature in God's creation. Because God is faithful to his own being, faithful to his own self-determination, and in this sense immutable in all his interactions with his creation, being God's creature implies an inalienable dignity for every creature. The justice of God implies in this way being invested with the particular dignity of being already justified as God's creature. ${ }^{10}$

When we take this way of understanding God's justice as the starting point for further reflections on the promise of the Reformation, we would have to say that God's creative and communicative justice is the fundamental dimension of every practical negotiation of justice and every discourse on justice. We do enter this discourse not as beings who have to earn recognition but who are already ultimately und unconditionally recognized by God the creator. Being recognized in this way by God means being dignified by a particular dignity which constitutes the right that this dignity is respected by others and so constitutes the obligation for others to respect this dignity and the right it entails unconditionally.

However, if we take Luther's discovery of God's justice as creative and communicative as the starting-point for further explorations of the relevance of Reformation theology for our understanding of justice we are also able to discover other dimensions of justice in Reformation theology. There is the dimension of commutative justice, philosophically defined as the equitable exchange of goods, constitutive for all contractual obligations. In Reformation theology, this is usually expressed in terms of God's free giving, even self-giving. In Luther's theology the language of God's self-giving is the common denominator of everything that the triune God communicates to his human creatures and so discloses God's being as "pure, unutterable love". ${ }^{11}$

God's Trinitarian self-giving has the purpose of bringing us to God in establishing communion with God. This communion is based on recognition: God's recognition of us as the recipients of his love whom he created in order to redeem

10 Cf. Christoph Schwöbel, "Recovering Human Dignity”, in: R. Kendall Soulen / L. Woodhead (eds), God and Human Dignity (Grand Rapids, MI: Eerdmans, 2006), 44-58.

11 The Book of Concord. The Confessions oft he Evangelical Lutheran Church, ed. by Robert Kolв and Timothy J. WENGERT (Minneapolis, MN: Fortress, 2000) [abbreviated: BC], 439. 
us and make us holy, but also our recognition of God as love in the Spirit and through the Son. Luther writes in Large Catechism:

For this very purpose he created us, so that he might redeem us and make us holy, and, moreover, having granted and bestowed upon us everything in heaven and on earth, he has also given us his Son and His Holy Spirit, through whom he brings us to himself. For ... we could never recognize the Father's favour and grace were it not for the Lord Christ, who is a mirror of the Father's heart. Apart from him we see nothing but an angry and terrible judge. But neither could we know anything of Christ, had it not been revealed by the Holy Spirit. (BC 439-40)

There is, of course, still a more specific exchange which Luther characterizes as a joyful exchange and as a mirabile commercium between Christ and us. This is, first of all, not an exchange of goods but an exchange of place, a transposition, not a transaction. This is the way in which Luther redefines commutative justice, the second dimension of justice. Christ takes our place as sinners in estrangement from God and exposed to the wrath of God's love, and we take his place as the Son of the Father in a filial relationship to God in the Spirit. Luther is quite clear that this particular form of exchange is exclusive to Christ, but it has inclusive consequences in that it is aimed at every Christian becoming Christ for the other. What Luther has in mind here, we can suppose, is the pattern of the story of the Judgement Scene in Matthew 25. 31-46. The standard of judgement for all is whether they recognize Christ in those who are desperately in need of mercy. Similarly, becoming Christ for one another, interceding for one another, is also a notable feature of the common priesthood of believers.

The crucial feature of divine self-giving in this sense is that it transcends the law of mutuality. God does not give himself in order to receive a proportional gift in return. If anything, there is an inverse proportionality when Christ takes our place, taking our sin upon himself, and we are invited to take his place as God's sons and daughters, as the recipients of Christ's justice. Similarly, the logic of becoming Christ for one another, of attending to those in need, presupposes that the needy are those who have nothing with which they could return the deeds of mercy.

Does transcending the law of mutuality have any significance for justice in the world or is justice in the world firmly bound to the mutuality of goods offered and returned, and so categorically different from God's justice? Even a brief reflection shows that the one-sidedness of non-mutuality is needed if we want to establish just relationships at all. If establishing a just relationship were conditional upon the anticipated response of the other party it would not be possible to establish a just relationship, to restore unjust relationships or to correct violated relationships. It is the one-sidedness of forgiveness, of absolution, of love that establishes just relationships. 
We can follow the understanding of Luther's view of God's justice as creative justice, justifying the sinner and Luther's redefinition of commutative justice in the transposition between Christ and us, also in reflecting on the third dimension of justice, justice as distributive justice. This dimension of the understanding of justice already played a major role in the conflict over indulgences und the interpretation of the "treasure of the church". According to Roman teaching in Luther's day, the treasure of the church is the sum of the merits of Christ and the saints which has accumulated because they have achieved merit in excess of what is required for satisfaction. Therefore the church can distribute the grace acquired by these merits - for example by offering indulgences. According to this understanding of the treasure of the church, going back to Alexander of Hales, the active justice of Christ, the saints and of all humans in acquiring merits or in requiring merits becomes the measure of justice. We are back to Luther's original question “How can I find a gracious God?” and his despair in never being able to fulfil the law of Christ.

Here we also have a radical change in the understanding of justice, rooted in a change in the understanding of the treasure of the church. Luther criticizes in thesis 56 of the 95 theses that "the true treasure of the church, out of which the Pope distributes indulgences, is not sufficiently known or discussed by the people". He immediately adds in thesis 58 that the merits of Christ and the saints cannot be what is referred to as the treasure of the church because, Luther says, the work of Christ and the saints always work grace for the inner man, the human being in relation to God, and cross, death and hell for the outer man, the human being in relation to the world. In other words: If the work of Christ and the saints is effective by itself without the Pope distributing its benefits then they cannot be regarded as the treasure of the Church which the Pope, as it is claimed by the indulgence preachers, has at his disposal. The new definition then comes in thesis 62: "The true treasure of the church is the most holy gospel of the glory and grace of God."

If the Gospel is the true treasure of the church, consisting of the two communicative attributes of God, glory and grace, then there is nothing for the Pope to distribute because God's glory and grace communicate themselves through God's self-presentation in the word of the gospel and in the visible words of the sacraments. Furthermore, it is no longer the need, the deficiency of sinners that defines the proportionate distribution of grace, but the abundance of God's grace and glory.

This also applies to God's justice. It is no longer understood as the distribution of object-like goods, like commodities, but as participation in personal communion. It is no longer based on the human deficiency of justice but on the abundance of creative justice, realized in God's Trinitarian work, and it is "dis- 
tributed" to sinners not as an objective commodity, but as personal communion, as the communicative participation in the benefits of Christ.

Does this have consequences for our understanding of distributive justice also in human society? Luther's view of the true treasure of the church at least challenges a scenario where, for instance, the basic economic problem is defined as the need to satisfy unlimited wants with limited resources. It also questions the underlying view of what it means to be human by identifying self-love, concupiscence and pride with Augustine as the characteristic marks of the psychopathology of sin. In contrast, love of God and neighbour, the generosity of sharing and the gratefulness for what God has done for us are seen as the marks of the life of faith. The problem of distributive justice is radically redefined if it is not based on a situation of deficiency but on the abundance of God's goods for us. Humans are no longer interpreted as competitors for scarce goods but portrayed as beneficiaries of God's generosity, as creatures of promise and therefore as co-operators with God in achieving his goal for his reconciled creation. The redefinition extends further where the distribution of goods is replaced by participation in personal communion.

The correlate of such a view of justice as recognition, gift and participation is a view of corrective justice which does not have as its guiding idea the recompensation for the ills that have been suffered by the victims of injustice but the restoration of their dignity and the reconstitution of community between perpetrators and victims.

In all these dimensions, God's justice is, according to Luther, to be understood as enabling justice, as the reconstitution of the ability to fulfil the will of God with desire and affection. This is a far more effective way of orienting human action than to present it with moral norms, because faith in God's justice has to be understood as the reconstitution of the human capacity to act, to be motivated by the need of the other and not by the desire to acquire merit for oneself. It is the reconstitution of the spontaneity to act justly and rightly.

This redefinition of justice which we have tried to develop with regard to the multi-dimensional understanding of justice as recognition, as commutative justice, rooted in gift-giving, as distributive justice, redefined in terms of participation and as corrective justice, redefined in terms of restorative justice, and as enabling justice is certainly part of the continuing promise of the Reformation.

\section{The Promise of Freedom}

The concept of freedom plays a key-role in Reformation theology and is given paramount significance in the preparations for the celebration of the 500 year 
anniversary of the Reformation. Freedom is "the modern universal", the most basic concept for the definition of modern and post-modern self-understanding. ${ }^{12}$ The view of Reformation theology on freedom, however, is a very particular view and cannot easily be reconciled with the modern rhetoric of freedom in its many varieties. Luther explored the notion of freedom both in his tract On the Freedom of a Christian in 1520, and in 1525 in his dispute with Erasmus of Rotterdam in his work with the title On the Bondage of the Will. Are freedom and the bondage of the will really compatible? Or should we just focus on one of the two works and discard the other - as many in the neo-Protestant tradition have done by rejecting the complicated and sometimes tortured reflections in On the Bondage of the Will as a relapse into scholastic modes of theologizing?

In On the Freedom of the Christian Luther develops the twofold thesis that a Christian is an entirely free lord over everything and subject to nobody - and that a Christian is entirely a serving servant and subject to everybody. This dialectical thesis is explained with the distinction between the "inner man" and the "outer man". This distinction is best explained in terms of two sets of relationships in which Christians, and every human being, exist. The one, inner man, are those relationships, which constitute the human being as a person, the other are those relationships, in which the human person leads an embodied life of faith. For Luther it is quite clear that we are not free if we are not liberated. He quotes John 8:36. "When the Son liberates you, you will be truly free." Analogously, we have already seen that we are not just, if we are not justified by God. The argument on freedom and justice runs largely parallel in On the Freedom of the Christian. Luther's thesis is that the freedom of the Christian cannot be constituted by external works of any kind but only by the divine Word as it is appropriated in faith. The underlying anthropological conviction is that human beings are not constituted by what they do but rather by what they are, and what they are is freely given to them by God. Faith means trusting in the God who gives us what we are. This has far-reaching implications since it implies that humans are not defined by their abilities or inabilities, by their capacities or incapacities, but by their faith in the relationship that has become certain for them as the fundamental relationship of their life. Humans are believing animals. Trust is the fundamental anthropological constant. In the framework of relationships, shaped by the fundamental relationship of ultimate trust, human abilities or inabilities find their definitive form. In this sense it is the Gospel as it is appropriated to us and put to

12 Cf. Christoph ScнwöвеL, "Imago Libertatis: Human and Divine Freedom“, in: Colin E. Gunton (ed.), God and Freedom. Essays in Historical and Systematic Theology (Edinburgh: T\&T Clark 1995), 57-81. 
use in faith that constitutes human freedom. This freedom becomes efficacious when the believer, on the basis of the promise of the Gospel as it constitutes the certainty of faith, ascribes to God truth and justice, by trusting unconditionally in the promise of the Gospel.

The most distinctive feature in On the Freedom of the Christian is the way in which Luther then describes the relationship between God and the soul in the language of nuptial mysticism as the union between Christ as the bridegroom and the soul as the bride, a marital union, sealed by the wedding band, in which they each fully participate in the possessions of the other. Christ takes upon himself all sin, evil and death as the wages of sin of the human soul which participates fully in Christ's justice, life, salvation. Luther writes:

Christ is full of grace, full of life and salvation; the soul full of sins, of death and damnation. When faith steps in in intercession it will occur that sins, death and hell belong to Christ, to the soul belong grace, life and salvation..$^{13}$

In this communion, the "goods" of Christ devour sin, death and hell and in this way the soul participates in the goods of Christ. Again we see the logic of fullness, of abundance at work which overcomes the logic of scarcity and deficiency on the part of the soul. For Luther this is a real exchange, based on the communicative presence of Christ in faith. Therefore, it is faith, qualified in this sense as communion with Christ and so as access to the communion of the Trinitarian life of God, which fulfils the first commandment: "You shall have no other God beside me."

Reading and re-reading On the Freedom of a Christian one wonders why Luther does not start with an analysis of freedom but with an analysis of faith. One can try to give an answer along the following lines. Faith as unconditional trust in God, as union with Christ, is the victory over all powers that enslave us or restrict our freedom. According to Luther, our freedom is most at risk where we try to constitute it by our own effort or when we trust in other "deities" than the triune God who unites himself to us in Christ through faith. In his explication of the First Commandment Luther offers a long list of idols humans are tempted to trust in: power, wealth, competence, social recognition and so on. However, these deities do not offer freedom. They enslave us because they exploit the deficiency of humans through which we desire what they have to offer. The only liberation form idolatry is faith in the one true God.

13 Martin Luther, Tractatus de Libertate Christiana/Abhandlung über die christliche Freiheit, in: Martin Luther, Lateinisch-deutsche Studienausgabe, Bd. 2: Christusglaube und Rechtfertigung, ed. by Johannes Schilling (Leipzig: EVA, 2006)101-187, 134: “Christus plenus est, gratia, vita, et salute Anima plena est peccatis morte et damnatione, Intercedat iam fides, et fiet, ut Christi sint peccata, mors et infernus. Animae vero gratia, vita et salus“. 
So far, we have not looked at the other aspect of freedom, the freedom for others, which includes that the Christian becomes a serving servant for others. "Christians", Luther writes, "do not live in themselves but in Christ and in their neighbour or they are not Christians. In Christ they live by faith, in the neighbour by love. By faith Christians are torn above themselves to God, conversely they fall below themselves through love on their neighbour." ${ }^{14}$ If we look at the way in which Luther describes Christian service as the freedom for the good of the neighbour it becomes clear that he is concerned with freedom not as a conceptual construct or a mental capacity but as a form of embodied freedom which understands the body, our corporeal existence as well as the social embodiment of the Christian community, as a communicative entity, as our communicative presence for the other and for the good of the other. Once our bodily existence is liberated from the service of our respective idols, it is liberated for the service of our neighbour. The source of this free service is the abundance of God's gifts for the believer, the norm of the appropriateness of such service for the neighbour is not obedience to a given norm, and be it a divine commandment, but the need and the plight of the neighbour. Such free service, Luther insists, can be free of all attention for social recognition, for praise or blame, for one's own benefit or harm. As we recognise in faith how much we were in need of God's mercy, we are made aware of the need of our neighbour so that in love we are Christs for one another and yet Christ is the same in everybody, so that we truly Christians. ${ }^{15}$

Does this view of Christian freedom fit together with Luther's view developed in conversation with Erasmus in On the Bondage of the Will? It seems to me that Luther deepens here his theological analysis of the nature of freedom. He seems to see freedom as ordered in a hierarchical structure. There is freedom of action (libertas), freedom of will (voluntas) and the highest level, the freedom to find orientation (arbitrium) in selecting the overall aims which provide orientation for our willing and acting. Humans do not possess this highest form of willing. Applied to humans it is a mere word. ${ }^{16}$ Strictly speaking, it can only be understood

14 Luther, De libertate, 174: "Christianum hominem non vivere in seipso, sed in Christo et proximo suo, aut Christanum non esse, in Christum per fidem, in proximo per charitatem, per fidem sursum rapitur supra se in deum, rursum per charitatem labitur infra se in Proxumum, manenes tamen semper in deo, et charitate eius".

15 LUther, De libertate, 166: “... sicut pater coelestis nobis in Christus, gratis auxiliatus est, ita et nos debemus gratis per corpus et opera eius, proximo nostro auxiliari, unusquisque alteri, Christus quidam fieri, ut simus mutuum Christi et Christus idem in omnibus, hoc est vere Christiani."

16 In the Heidelberg Disputation (1518) Luther defends the proposition XIII: "Liberum arbitrium post peccatum, res de solo titulo, et dum facit, quod in se est, peccat mortaliter.” Martin LutHER, Lateinisch-deutsche Studienausgabe, Bd. I, ed, by Wilfried HärLE (Leipzig; EVA, 2006), 35-69, 
as an exclusive divine attribute. God is the only one who freely determines his own future. ${ }^{17}$ This, in fact, is what it means to be God, and since in his selfdetermination his goal for his creation is included, God's free will is for all beings who are not God the necessity in the framework of which they exercise their finite freedom of action and their limited freedom of the will. Therefore it is necessary, if one wants to live a pious life, to rely on the main parts that, for Luther, make up the sum of all things Christian and which our self-knowledge and the knowledge and glory of God depend: on the one hand, the distinction between God's work and ours and, on the other, knowing whether God knows something contingently or whether we do everything by necessity. ${ }^{18}$ For Luther it is clear that as creatures humans never had free will in this sense. Even in paradise Adam and Eve had a bound capacity for orientation, dependent on being granted orientation by God's word. The predicament of sin is that as fallen creatures, whatever we decide independently, is a decision against God. This orientation towards that which contradicts God cannot be overcome by human creatures themselves. If it were otherwise, they would be the creator, they would be God. As Luther already stated in his disputation "Against scholastic theology", humans cannot naturally let God be God; rather, they want to be God and want God not to be God $^{19}$ We can only find the right orientation for our willing and acting, if God by his Spirit grants

46. In De servo arbitrio Luther then asserts that freedom of the will as the capacity to select ones owns aims and to achieve them successfully is clearly a divine attribute. Only God, Luther states with reference to Psalm 139, can and does everything that he intends in heaven and on earth: “... liberum arbitrium esse plane divinum nomen, nec ulli posse competere quam soli divinae maiestati, Ea enim potest et facit (ut Psalmus canit) Omnia quae vult in coelo et in terra." Op. cit., 294.

17 Cf. Christoph SchwöвеL, "Promise and Trust. Lutheran Identity in a Multicultural Society“, in: C.-H. Grenholm/G. Gunner (eds.), Justification in a Post-Christian Society, (Eugene, OR: Pickwick, 2014), 15-35.

18 Luther, De servo arbitrio: "Oportet igitur cetrissimam distinctionem habere, inter virtutem Dei et nostrum, inter opus Dei et nostrum, si volumus pie vivere. Ita vides, hoc problema esse partem alteram totius summae Christianarum rerum, in quo pendet et periclinatur cognition sui ipsius, cognition et Gloria Dei.” Op. cit , 246, 248. “Altera pars summae Christanae est, Nosse, an Deus contingenter aliquid praesciat, et an Omnia faciamus necessitate.” Op. cit , 248. The second part of what makes up the sum of Christianity Luther asserts much more straightforwardly in the assertion that God foreknows nothing contingently, but that he foreknows, decides and effects everything by his unchangeable, eternal and infallible will. "Et itaque et hoc imprimis necessarium et salutarium Christiano, nosse, quod Deus nihil praescit contingenter, sed quod Omnia incommutabili et aeterna, infalliinilique voluntate et praevidet et proponit et facit.” Op. cit., 250.

19 Martin Luther, Disputatio contra scholasticam theologiam, in: Martin Luther, Lateinischdeutsche Studenausgabe, Bd. I, ed. by Wilfried HärLE (Leipzig; EVA, 2006), 19-34, 22: „xvii Non potest homo naturaliter velle deum esse deum. xviii Immo velle se esse deum, et deum non esse deum.“ 
certainty concerning the Gospel of Christ and so discloses his aims for us. Wherever that happens, we are enabled to cooperate with the will of God in accordance with the destiny of God's creatures to find their fulfilment in the communion of the triune God with his reconciled creation. Claiming like Erasmus that by our own free will we can find orientation towards the good - and be it for the best moral reasons - is in Luther's view just another form of idolatry.

It is this connection between the loss of freedom and idolatry that provides the element of Reformation theology that can claim the highest relevance in our contemporary situation. We can easily point to the idols widely worshipped in our world that restrict our freedom because they proliferate the illusion that our freedom is ultimately self-constituted and that our salvation consists in being on the side of the winners in the competition of life: political power, wealth, the market, recognition and admiration by others as they appear to be created by the social media, beauty, bodily fitness, spiritual self-perfection etc. The list of idols where something finite is invested with infinite value is potentially endless. It is not difficult to show how these idols restrict and ultimately destroy our freedom to act and our freedom of will, because they falsely offer ultimate orientation. Luther's message is that where we are liberated by the Gospel of Christ and by living in communion with Christ share in all his goods, the idols that feed on our perceived deficiencies vanish, because we share in Christ's abundance. Where our world is depopulated of quasi-religious idols it becomes worldly again, a matter of responsible praxis for the common good of society but not a path to salvation. It follows for Luther that serving God does not require specific religious acts but consists in witnessing to God's justice and freedom and communicating God's love in our common everyday life.

It would be too easy to see "the world" as the place where the idols still rule until they are made to disappear by the one true God. The Reformation was not an attempt to reform the world so that it can get rid of idolatry. It was triggered by the presence of the idols right in the middle of the Church, distorting the true message of the Gospel and the true calling of the Church. Can we also find evidence for that in our churches? Could it be that under the umbrella of the confession to the one true God the idols reign supreme: striving for power, greed for more and more wealth, the desire to find recognition in the eyes of others, the striving for self-perfection? If that were the case, then our churches would indeed need to be reminded of the theological insights of the Reformation, then they would indeed be in need of - Reformation. 


\section{An Embodied Promise: The Church as Creature, Witness and Instrument of Christ's Presence}

It would be tempting to follow these theological reflections on justice and freedom in Reformation theology with a programme of church reform, laying down rules and recommendations for new church structures and suggesting new policies for the church. This, however, would entirely obfuscate the impulse of the Reformation, and this has happened often enough in the history of our churches. It amounts to nothing less than turning Gospel into law. Many years ago Robert Jenson has pointed to the different logic of law and Gospel..$^{20}$ The law follows the pattern: "if - then": "If you meet these requirements - then you will." We notice immediately that it is this understanding of justice and freedom which is rejected in Reformation theology because it make justice dependent on human actions and freedom dependent on human capacities. The logic of the Gospel is entirely different. It has the pattern: Because - therefore. This is Gospel: Because I am you are. Because I am just - you are justified as you trust my promise of justice. Because I am the giver of all gifts - you are my gifted creature. To state it boldly: If it is right that the Church is the creature of the Gospel, she is an embodied promise and the embodied human response of faith. Both are nothing less than the presence of Christ in the Church.

It is a salutary reminder that the Reformation is not the establishment of the Christian community in a non-Christian environment. It is literally re-formation, the redirection of the Christian church to that which gives it its form, its particular social life as the embodiment of the witness to its foundation. The Reformation was a call to the Church to discover anew what she truly is, the creature of the Gospel or "the Kingdom of Christ already present in mystery", as Lumen Gentium 3 puts it, and so is called to shape her life according to what she already is and according to what she is called to become. It may be that our churches may have to experience first of all the work of the law and to suffer what the law inflicts, the painful insight that by their own means our churches will never be what they are called to be. It may be that our churches in the West and in the East will have to experience the effects of failing before the requirement of the law, death and despair, before they discover anew that the Church lives by what it is because of Christ the embodied promise of God's justice and freedom for all humankind.

20 Cf. Robert W. Jenson, Story and Promise. A Brief Theology of the Gospel of Jesus (Philadelphia: Fortress, 1973, 6-9. 
Whereas the law can be taught by instruction, the Gospel can only be proclaimed in word and sacraments. This proclamation, however, must be placed in the context of living the life of an embodied promise. What the Church is as the body of Christ, the embodied promise of the Gospel, can only be grasped by initiation and example. Life in a community whose life is not determined by the past but shaped by a future opened up in the promise of the Gospel can only be understood by participating in it. Only initiation and example can make clear what the church already is: the witness and instrument of the presence of Christ in the world. 